\title{
Costs and benefits of preparing existing Danish buildings for low-temperature district heating
}

Østergaard, Dorte Skaarup; Svendsen, Svend

Published in:

Energy

Link to article, DOI:

10.1016/j.energy.2019.03.186

Publication date:

2019

Document Version

Peer reviewed version

Link back to DTU Orbit

Citation (APA):

Østergaard, D. S., \& Svendsen, S. (2019). Costs and benefits of preparing existing Danish buildings for lowtemperature district heating. Energy, 176, 718-727. https://doi.org/10.1016/j.energy.2019.03.186

\section{General rights}

Copyright and moral rights for the publications made accessible in the public portal are retained by the authors and/or other copyright owners and it is a condition of accessing publications that users recognise and abide by the legal requirements associated with these rights.

- Users may download and print one copy of any publication from the public portal for the purpose of private study or research.

- You may not further distribute the material or use it for any profit-making activity or commercial gain

- You may freely distribute the URL identifying the publication in the public portal

If you believe that this document breaches copyright please contact us providing details, and we will remove access to the work immediately and investigate your claim. 


\section{Accepted Manuscript}

Costs and benefits of preparing existing Danish buildings for low-temperature district heating

Dorte Skaarup Østergaard, Svend Svendsen

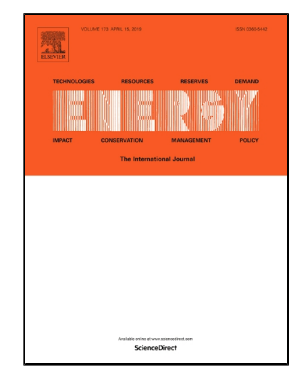

PII: $\quad$ S0360-5442(19)30606-1

DOI: $\quad$ 10.1016/j.energy.2019.03.186

Reference: $\quad$ EGY 15022

To appear in: Energy

Received Date: $\quad 17$ September 2018

Accepted Date: $\quad 31$ March 2019

Please cite this article as: Dorte Skaarup Østergaard, Svend Svendsen, Costs and benefits of preparing existing Danish buildings for low-temperature district heating, Energy (2019), doi: 10.1016 /j.energy.2019.03.186

This is a PDF file of an unedited manuscript that has been accepted for publication. As a service to our customers we are providing this early version of the manuscript. The manuscript will undergo copyediting, typesetting, and review of the resulting proof before it is published in its final form. Please note that during the production process errors may be discovered which could affect the content, and all legal disclaimers that apply to the journal pertain. 


\title{
Costs and benefits of preparing existing Danish buildings for low-temperature district heating
}

Dorte Skaarup Østergaard*, Svend Svendsen

*Corresponding author, Tel. +45 422518 80, E-mail address: dskla@byg.dtu.dk.

Technical University of Denmark, Department of Civil Engineering, Brovej, Building 118, DK-2800 Kgs. Lyngby, Denmark.

\begin{abstract}
This paper aims to provide an overview of the costs and benefits of preparing existing space heating systems for low-temperature district heating. Necessary heating system improvements were assessed based on previous work carried out on the topic. This included evaluating the necessity of installing larger heating elements and improving heating system control. The costs of the identified heating system improvements were then estimated and compared with the savings achieved if district heating temperatures were lowered, from the perspective of both the total Danish energy system and the individual district heating customers. The investigations resulted in simple payback times of 1.2-4.3 years from an energy system perspective and 0.3-18.7 years for an individual district heating customer. The current study thus indicates that it is economically feasible to invest in an improved heating system control to enable a reduction in the district heating return temperatures.
\end{abstract}

Keywords: $4^{\text {th }}$ generation district heating; space heating; radiators; heating system control; lowtemperature heating

\section{Introduction}

Low-temperature district heating is a promising solution for energy efficiency improvements in the future heating sector. This is because the efficiency of many renewable heat sources, such as heat pumps, solar heating, geothermal heating, and biomass boilers with flue gas condensation, is greatly increased if temperatures are lowered [1]. Furthermore, a reduction in district heating temperatures will reduce the 
heat losses from the district heating network. For these reasons, low-temperature district heating can potentially play an important role in the future European energy system [2].

Low-temperature district heating can be implemented in new areas with low-energy buildings [3-6] or through a transition to lower temperatures in a current system with existing buildings [5-9]. Because existing buildings form a majority of the building stock, the main challenge is to reduce the temperatures in the existing networks. In this case, it is necessary to reduce both supply and return temperatures equally to meet the hydraulic limitations of the existing district heating pipes. Focus should therefore be placed on a reduction in the return temperature as well as a reduction in the supply temperature.

A reduction of the district heating return temperatures would be beneficial even today. The current energy system is largely based on condensing biomass or gas boilers and waste incineration, and a reduction in the district heating return temperature makes it possible to extract a greater amount of heat from these energy plants [10]. Moreover, a reduction in return temperatures reduces the heat losses from network pipes and increases the capacity of the network, which can allow expansion to new customers or reduce pumping costs [11]. The savings achieved from a reduced return temperature differ greatly depending on the heat source in question [12] and can be determined in many different ways, considering, for example, the possibility of expanding the district heating network to new customers or avoiding the replacement of current pipes [11]. Frederiksen \& Werner [10] presented an illustration of the savings expected in 27 Swedish district heating companies, showing average savings on the order of EUR 0.15 per $\mathrm{MWh}{ }^{\circ} \mathrm{C}$ but ranging everywhere from EUR 0.03 to 0.38 per $\mathrm{MWh}{ }^{\circ} \mathrm{C}$.

When the return temperature has been reduced, it is possible to reduce the supply temperature by a corresponding amount. This is particularly important in the long run as heat pumps and solar heating are expected to deliver a greater amount of heating. If the district heating temperatures can be reduced from $80^{\circ} \mathrm{C} / 45^{\circ} \mathrm{C}$ to $55^{\circ} \mathrm{C} / 25^{\circ} \mathrm{C}$, the COP of a heat pump based on industrial waste can increase from 4.2 to 7.1 . Similarly, the cost of solar thermal will decrease by approximately $30 \%$ owing to the increased efficiency of 
solar panels [13]. The optimal temperature level in a district heating network therefore depends on the available heat sources, and they can be further affected by other individual parameters, such as the heat loads in the system and the age of the existing district heating pipes [14]. On this note, Ommen et al. [15] recommended optimal supply temperatures in the Copenhagen area of approximately $65-70^{\circ} \mathrm{C}$, whereas other studies have shown that ultralow-temperature district heating can be a feasible solution in small district heating networks with low heat density [16]. On a general level, however, Lund et al. [17] showed the feasibility of reducing Danish district heating supply and return temperatures to an average of $55^{\circ} \mathrm{C} / 25^{\circ} \mathrm{C}$, and current estimates show that, if such a temperature reduction is implemented in the Danish district heating systems, this will generate annual savings of EUR 10 per MWh of district heating produced [13].

To a large extent, the reduction in both supply and return temperatures depends on the components installed in the buildings. For example, current heating systems were designed for supply and return temperatures as high as $90^{\circ} \mathrm{C} / 70^{\circ} \mathrm{C}[18,19]$, and it must be ensured that these heating systems can cover the heat demand of the buildings at lower temperatures before the district heating supply temperature is reduced. The district heating return temperature generally depends on the design and control of the inhouse installations $[14,20]$, and if the in-house installations do not work properly, this can easily lead to higher district heating return temperatures than necessary. This can make it difficult to reduce the supply temperature, because there must be a certain cooling requirement of the district heating water for the right amount of heat to be delivered within the hydraulic capacities of the district heating pipes. To implement low-temperature district heating, it is therefore necessary to prepare the heating installations in existing buildings for low-temperature heating.

To assess the overall feasibility of implementing low-temperature district heating in existing building areas, it is necessary to estimate the costs of the necessary improvements in current heating system installations. However, this is difficult because the costs consist of many different strands that all should be considered. 
This study set out to provide new knowledge on this topic by combining previous studies on these strands to provide a new overview of the overall feasibility of improving existing space-heating systems to implement low-temperature district heating.

\subsection{Aim of study}

The aim of this study was to evaluate the costs and benefits of enabling current space heating systems in existing buildings to achieve the transition to low-temperature district heating by 2050. First, the necessary heating system improvements were evaluated by combining and discussing the results of four years of research on the state of Danish heating systems. Second, we estimated the cost of carrying out the identified necessary improvements, both for the individual homeowner and for the total Danish energy system. Finally, we calculated the simple payback time of carrying out the improvements by comparing the estimated costs to the savings that can be achieved if district heating temperatures are lowered.

\section{Method}

In this study, the costs and benefits of converting existing heating systems for low-temperature district heating were evaluated from a long-term perspective. The analysis focused on the possibility to reduce typical heating system temperatures to $55^{\circ} \mathrm{C} / 30^{\circ} \mathrm{C}$ in order to support a transition to low-temperature district heating in Danish district heating systems that are currently operated with average annual energyweighted temperature levels of $80^{\circ} \mathrm{C} / 45^{\circ} \mathrm{C}$. We assumed that the transition in the temperature levels of the district heating networks and the improvements in building installations will take place over a long timeframe between now and 2050. In such a lengthy time period, many of the installations will be replaced at the end of their lifetimes; thus, in these cases, at least the improvements will incur very little extra expenditure. Furthermore, there will be improvements in the insulation level of the district heating network and energy savings in the building stock.

The study consisted of three parts. In the first part, we summarised the results of previous studies by the authors on the necessity of improving current heating system installations to enable the implementation of 
low-temperature district heating. In the second part, we estimated the costs related to carrying out these improvements, both from the perspective of the individual homeowner and from an overall energy system perspective. In the last part, we assessed the simple payback time of implementing low-temperature district heating by comparing the estimated costs with the economic savings that can be achieved by the individual homeowner and for the total energy system if district heating temperatures are lowered. The following sections describe the details of the methods used in each of the three parts of the study.

\subsection{Evaluation of necessary heating system improvements}

Two main factors affect the possibility of lowering the heating system temperatures in existing heating systems. First, the heating elements must be large enough to emit enough heat to provide a comfortable thermal indoor climate even if heating system temperatures are lowered. This is a concern because the heat emitted from a heating element is reduced if the mean surface temperature of the element is reduced. Second, the heating system control must work properly to ensure the lowest possible heating system temperatures. If current heating elements are large enough to ensure necessary thermal comfort, and heating system control can easily be made to work properly, it should be easy to convert existing heating systems to low-temperature heating. However, little is known about the heating system installations in existing buildings, so these two factors are not easily assessed. During recent years, the authors therefore carried out research on these topics in the context of Danish buildings. In this study, we combine the results of this research to assess the heating system improvements necessary to enable the conversion to low-temperature district heating.

The sizes of existing heating elements in the Danish building stock were investigated through four publications $[19,21-23]$. Two of the publications addressed overall investigations of the tendencies in Danish heating systems $[19,21]$ and the other two discussed detailed investigations of the heating systems in eight specific single-family houses $[22,23]$. In all publications, a main theme was to compare the heating system dimensions and heat demand in the investigated Danish houses to estimate the potential for reducing the heating system temperatures. This is because the potential for heating a building with low- 
temperature district heating generally depends on the relationship between the heat output of the heating elements installed and the heat loss of the building.

In this study, we have chosen to summarise the findings of the four articles with reference to the design conditions of the buildings and heating systems. This makes it possible to provide a simple reference for the heating system dimensions and compare heating systems installed in many buildings irrespective of the original design heating system temperatures and the individual energy renovations carried out. Design conditions in Denmark are described in DS 418 [24] and are based on a design outdoor temperature of $-12^{\circ} \mathrm{C}$ and a design indoor temperature of $20^{\circ} \mathrm{C}$. No heat gains are included when the heat losses from the building are calculated. Design heating system supply and return temperatures varied throughout the 1900 s, from $90^{\circ} \mathrm{C} / 70^{\circ} \mathrm{C}$ at the beginning of the 1900 s to $70^{\circ} \mathrm{C} / 40^{\circ} \mathrm{C}$ in recent building regulations and $60{ }^{\circ} \mathrm{C} / 40^{\circ} \mathrm{C}$ in the current building regulations [19].

The relationship between the heat output of the heating elements and the heat loss of the buildings in the design conditions is given by a factor, denoted the radiator factor and defined according to Equation 1.

Equation 1 Radiator factor $=\frac{\text { Design heat output of heating elements at temperatures } 70^{\circ} \mathrm{C} / 40^{\circ} \mathrm{C}[\mathrm{W}]}{\text { Design heat loss of buildings }[\mathrm{W}]}$

This means that a heating system with a radiator factor of 1 corresponds exactly to what is expected according to the defined design conditions, whereas a heating system with a radiator factor above 1 is larger than expected. A radiator factor above 1 thereby indicates that the heating system is well suited for low-temperature heating. Based on the findings of the studies, we aimed to estimate how many radiators must be replaced to implement low-temperature space heating on a broad scale.

The evaluation of the current heating system control was conducted with reference to three studies $[22,23,25]$. These studies investigated the heating system control and design in nine existing Danish singlefamily houses where the space heating supply temperatures were lowered. The studies included measurements of the overall heating system supply and return temperatures, with more detailed 
measurements of the return temperatures from radiators in some of the houses. This made is possible to evaluate whether heating system temperatures in existing building can be simply lowered by reducing the supply temperature to the heating system or whether certain problems with heating system design and control cause problems with high heating system return temperatures.

In this study, we summarised the findings of the previous work by providing insight into the measured heating system temperatures and the identified problems in heating system design and control, which in some cases were found to be a barrier to lower the heating system temperatures. Based on this input, we defined four different scenarios for heating system improvements that could be necessary in an individual dwelling to reduce the district heating return temperatures, along with two scenarios for necessary heating system improvements of Danish buildings in general.

\subsection{Estimated costs of heating systems improvements}

The component costs and installation time for the various necessary heating system improvements identified in the study were estimated based on a combination of communication with sector representatives and data on average prices from Danish construction projects given in Molio price data [26]. The total cost of each heating system improvement was calculated by adding the component costs to the salary of the craftsman performing the installation of the component according to Equation 2 . The salary of the craftsman was assumed to be EUR 70 per hour.

Equation 2 Total component cost $\left[\frac{E U R}{\text { unit }}\right]=$ Work hours $\left[\frac{\text { hours }}{\text { unit }}\right] \cdot 70 \frac{\text { hour }}{\text { hour }}+$ Component cost $\left[\frac{\text { unR }}{\text { unit }}\right]$

The study included two new components for which the price and necessary working hours were not known from current experience. For these products, the costs were estimated with reference to prices of similar current components. 


\subsection{Costs of preparing typical Danish buildings for low-temperature district heating}

To estimate the costs of preparing the heating systems in typical existing Danish buildings for lowtemperature district heating, we first defined two standard building typologies - a standard single-family house and a standard apartment building. The standard single-family house was assumed to have an annual heat consumption for space heating of $15 \mathrm{MWh}$, and the heated floor area was assumed to be 150 $\mathrm{m}^{2}$ with ten radiators. The standard apartment building was assumed to have an annual heat consumption for space heating of $183 \mathrm{MWh}$ with 130 radiators in a total heated area of $2000 \mathrm{~m}^{2}$. The heat loss in the district heating network was assumed to be $19 \%$ [13], so the heat production required to satisfy these heat demands was assumed to be $17.9 \mathrm{MWh}$ and $217.8 \mathrm{MWh}$, respectively. Table 1 summarises the key data on the defined standard building typologies.

Table 1. Definition of standard building typologies

\begin{tabular}{|l|l|l|l|l|l|}
\hline & $\begin{array}{l}\text { Heat demand } \\
{\left[\mathrm{kWh} / \mathrm{m}^{2}\right]}\end{array}$ & $\begin{array}{l}\text { Heat demand } \\
{[\mathrm{MWh} / \text { year }]}\end{array}$ & $\begin{array}{l}\text { Heat demand incl. heat } \\
\text { loss [MWh/year] }\end{array}$ & $\begin{array}{l}\text { Heated floor } \\
\text { area }\left[\mathrm{m}^{2}\right]\end{array}$ & $\begin{array}{l}\text { Number of } \\
\text { radiators [no.] }\end{array}$ \\
\hline Single-family house & 100 & 15 & 17.9 & 150 & 10 \\
\hline Apartment building & 91.5 & 183 & 217.8 & 2000 & 130 \\
\hline
\end{tabular}

To investigate the cost incurred by individual homeowners to implement the identified necessary heating system improvements, we considered the four different scenarios defined according to the results of previous research. The scenarios included four different technical solutions to reduce heating system temperatures according to the necessary heating system improvements identified in the study. The customer costs of implementing each solution were then calculated by multiplying the total component cost by the number of components needing replacement according to Table 1 . The calculation was performed via Equation 3 for both the standard single-family house and the standard apartment building. As an example, the cost of replacing the radiator valves in a standard single-family house would be calculated by multiplying the total cost of installing one new radiator valve by 10 , because there are assumed to be 10 radiators in a standard single-family house. 
Equation $3 \quad$ Customer cost $[E U R]=$ Total component cost $\left[\frac{E U R}{\text { unit }}\right] \cdot$ No. of building units $[$ unit $]$

The costs of preparing the heating systems of the buildings in the total Danish energy system for lowtemperature district heating were calculated in EUR per MWh of heat production. This was performed with reference to the heat produced to satisfy the heat demand in the standard buildings defined in Table 1 . For example, the cost of installing new valves in typical Danish apartment buildings was calculated by multiplying the cost of installing one new valve by the number of valves in the standard apartment building and dividing this number by the total heat production necessary to cover the demand of the building. The calculation was performed according to Equation 4.

Equation $4 \quad$ Energy system $\operatorname{cost}\left[\frac{E U R}{M W h}\right]=\frac{\text { Total component cost }\left[\frac{E U R}{\text { unit }}\right] \cdot \text { No. of building units }[\text { units }]}{\text { Heat production for building }[M W h]}$

The energy system costs were calculated for the two scenarios for necessary heating system improvements in the Danish buildings defined from the analysis of previous research results. This was performed by multiplying the energy system cost for each type of heating system component with the expected percentage of components needing replacement and then summing the total cost of all necessary improvements, according to Equation 5.

Equation $5 \quad$ Total energy system cost $\left[\frac{E U R}{M W h}\right]=\sum\left(\right.$ energy system $\operatorname{cost}\left[\frac{E U R}{M W h}\right] \cdot$ No. of buildings $\left.[\%]\right)$

\subsection{Savings and simple payback time for the individual homeowner}

The savings realised by individual homeowners when implementing heating system improvements that lower the heating system temperatures were calculated for two different customer cases. The first case was a single-family house with an average annual return temperature of $40^{\circ} \mathrm{C}$, which must be reduced to $30{ }^{\circ} \mathrm{C}$. The second case was an apartment building with an average annual return temperature of $53{ }^{\circ} \mathrm{C}$, which must be reduced to $30^{\circ} \mathrm{C}$. The actual savings realised by homeowners depend on the price structure of the individual district heating companies. Because reductions in the return temperatures lead to savings 
in the total district heating system, it is not uncommon for Danish district heating companies to charge their customers according to the return temperature they deliver to the district heating network. In this study, we investigated the savings realised by customers in two different Danish cities-Copenhagen area $(\mathrm{CPH})$ and $\mathrm{H} ø \mathrm{je}$ Taastrup (HT) - when the customers improve their heating system to reduce the return temperature.

In Copenhagen, the customer pays an extra tariff if the average annual cooling of the district heating water is less than $27^{\circ} \mathrm{C}$, whereas they receive a discount if it is more than $37^{\circ} \mathrm{C}$. With an average annual supply temperature of $80^{\circ} \mathrm{C}$, these temperatures correspond to average annual return temperatures of $53^{\circ} \mathrm{C}$ and $43^{\circ} \mathrm{C}$, respectively. Both the tariff and discount are rated at EUR 0.72 per ${ }^{\circ} \mathrm{C}$ per MWh of heat consumed. Considering only return temperatures below $53^{\circ} \mathrm{C}$, the savings realised by a customer in Copenhagen when the return temperature is reduced can be calculated according to Equation 6.

Equation $6 \quad$ Saving $_{C P H}[$ EUR $/$ year $]=\left(43{ }^{\circ} \mathrm{C}-T_{R, \text { new }}\left[{ }^{\circ} \mathrm{C}\right]\right) \cdot \Phi[\mathrm{MWh} /$ year $] \cdot 0.72 \mathrm{EUR} /{ }^{\circ} \mathrm{C} / \mathrm{MWh}$

where $T_{\mathrm{R}, \text { new }}$ is the new district heating return temperature obtained by the customer, and $\Phi$ is the annual heat consumption of the customer.

In Høje Taastrup, the customers receive a discount or must pay a tariff if their average annual return temperature is below or above $46^{\circ} \mathrm{C}$, respectively. Both the tariff and discount are rated at EUR 1.28 per ${ }^{\circ} \mathrm{C}$ per MWh heat consumed. The savings realised by customers in $\mathrm{H} \varnothing \mathrm{je}$ Taastrup who reduce their return temperature can thus be calculated according to Equation 7.

Equation $7 \quad$ Saving $_{H T}[$ EUR $/$ year $]=\left(T_{R, \text { old }}\left[{ }^{\circ} \mathrm{C}\right]-T_{R, \text { new }}\left[{ }^{\circ} \mathrm{C}\right]\right) \cdot \Phi[\mathrm{MWh} /$ year $] \cdot 1.28$ EUR $/{ }^{\circ} \mathrm{C} / \mathrm{MWh}$ where $T_{\mathrm{R}, \text { old }}$ and $T_{\mathrm{R}, \text { new }}$ are the old and new customer district heating return temperatures, respectively, and $\Phi$ is the annual heat consumption of the customer. 
Finally, the simple payback time of the customer investments was calculated by comparing the estimated costs of the homeowners to the savings realised for the two scenarios, according to Equation 8.

Equation $8 \quad$ Simple payback time $[$ years $]=\frac{\text { Customer } \operatorname{cost}[\text { EUR }]}{\text { Savings }\left[\begin{array}{l}\text { Ever } \\ \text { year }\end{array}\right]}$

\subsection{Savings and simple payback time for the total energy system}

The annual savings achieved in the Danish energy system if low-temperature district heating is implemented by 2050 were given with reference to [13]. In this study, the total annual savings are estimated to be EUR 10 per MWh per year. The simple payback time of investments in improving existing heating system installations to allow implementation of low-temperature district heating in the total Danish energy system was then calculated by comparing the costs of implementing the necessary heating system improvements in the Danish building mass with the saving of $10 \mathrm{MWh}$ per MWh per year, according to Equation 9.

Equation 9 Simple payback time $[$ years $]=\frac{\text { Total energy system cost }\left[\frac{E U R}{M W h}\right]}{10 \frac{E U R}{M W h} / \text { year }}$

\section{Results}

\subsection{Dimensions of current heating elements}

Fig. 1 summarises the results of radiator dimensions in existing houses [19,21-23]. The blue bar represents the radiator factors estimated for Danish single-family houses in different stages of energy renovation, as described in our theoretical study [19]. The lower limit of the bar represents a situation in which the only energy renovations included are the installation of thermo-windows in houses from before 1950 and a minimum insulation level of $50 \mathrm{~mm}$ under all roofs of the houses. The upper limit of the bar represents a case in which all windows have been replaced with new double-glazing low-energy windows, all roof constructions included $100-200 \mathrm{~mm}$ of insulation, and all cavity walls and floors over unheated basements were equipped with $60 \mathrm{~mm}$ and $100 \mathrm{~mm}$ insulation, respectively. The boxes and whiskers represent the results of an analysis of data from 1645 Danish houses [21]. The box marks the range of the radiator factors 
in $25-75 \%$ of the houses analysed, and the top and bottom whiskers represent the top $5 \%$ and bottom $5 \%$ of radiator factors, respectively. Finally, the red crosses indicate the radiator factors of houses in specific case studies $[22,23]$.

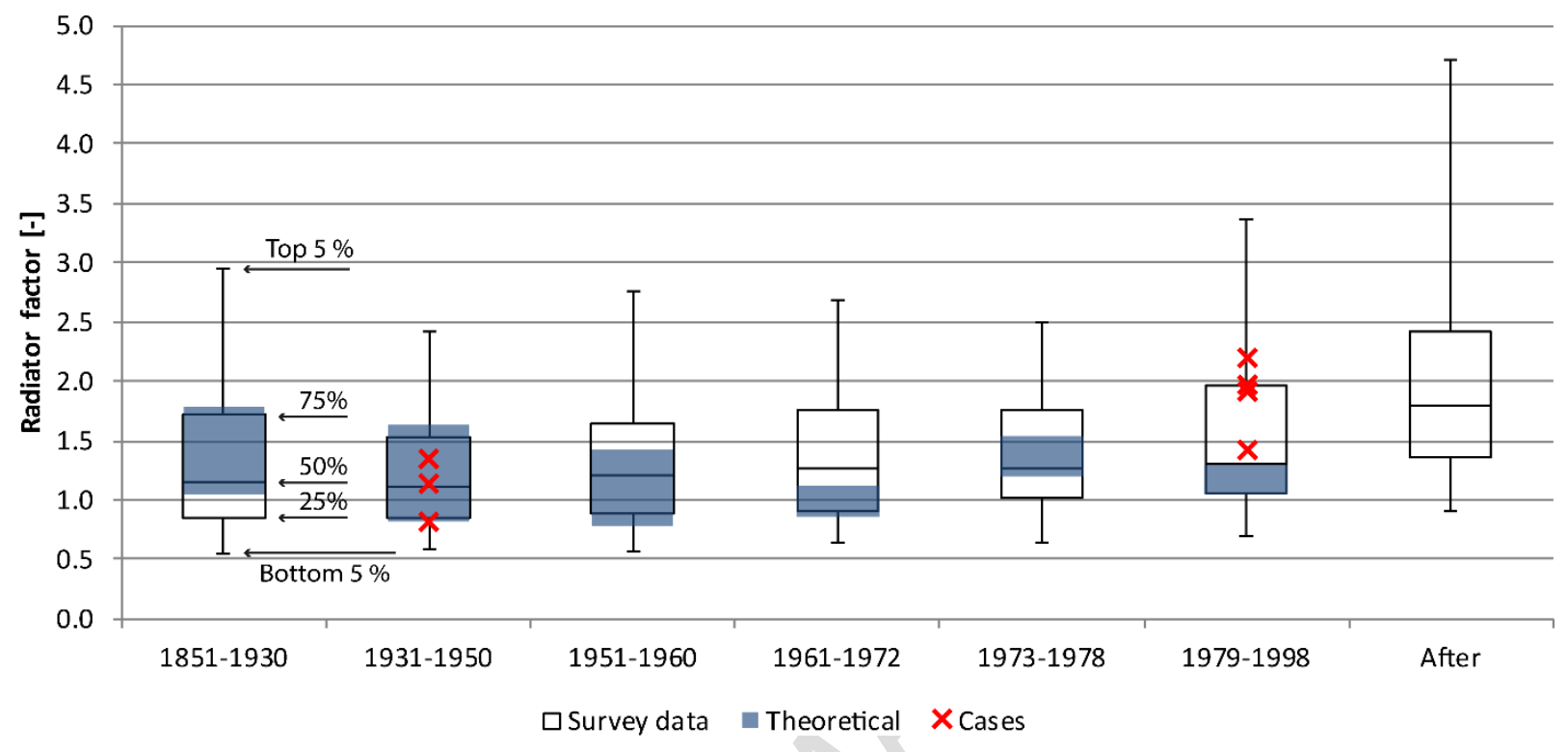

Fig. 1. Radiator factors of houses investigated in four studies on heating system dimensions $[19,21,22,25]$

Fig. 1 shows that most existing heating systems are over-dimensioned relative to the current heat loss of the buildings with heating system temperatures of $70^{\circ} \mathrm{C} / 40^{\circ} \mathrm{C}$, because most heating systems have a radiator factor above 1.0. The blue bars show that the radiator factors will generally be between 1.2 and 1.7 if existing houses are assumed to go through reasonable energy renovations in the years between now and 2050. This was also found in the investigation of the 1645 Danish houses, in which it was estimated that only $8 \%$ of existing houses will have heating systems with a radiator factor below 1.0 if the buildings are renovated to have a maximum design heat demand of $60 \mathrm{~W} / \mathrm{m}^{2}$, which corresponds to a heat demand of approximately $125 \mathrm{kWh} / \mathrm{m}^{2}$ per year [21]. If the heating system is dimensioned properly in accordance with the design temperatures of $70^{\circ} \mathrm{C} / 40^{\circ} \mathrm{C}$, it is possible to use much lower temperatures during most of the year, because heat gains reduce the demand for additional heating, and actual outdoor temperatures are generally far above $-12{ }^{\circ} \mathrm{C}[19,21]$. However, even if some heating systems have a radiator factor below 
one, this will not necessarily cause great problems, because it will mainly lead to increased return temperatures from these houses. Furthermore, even when the heating elements in a building have an average radiator factor below one, this does not mean that all radiators must be replaced to bring the heating system up to date. The studies estimated that, to ensure that the preferred occupant comfort is maintained when heating system temperatures are kept low, it is relevant to replace only up to $40 \%$ of the radiators in houses with under-dimensioned heating systems [22].

Based on the results of the summarised studies, the following assumptions were therefore taken regarding the need to replace current heating elements to reduce heating system temperatures in the future:

- In an individual building where the heating system is too small to ensure proper thermal comfort if heating system temperatures are lowered, it is assumed that $40 \%$ of the radiators must be replaced.

- For the Danish building mass, it is assumed that the heating system dimensions in $8 \%$ of the buildings are too small to allow a general reduction of the heating system temperatures by 2050 . In these buildings, it is assumed that $40 \%$ of the radiators will be critical and need to be replaced. This means a total of approximately $3 \%$ of the radiators in the existing building mass will need to be replaced.

\subsection{Heating system control}

The overall heating system measurements revealed that heating system temperatures were already low in six of the houses investigated [25,27]. Fig. 2 shows the heating system temperatures measured in two of these houses, which were successfully heated with average heating system supply and return temperatures as low as $45^{\circ} \mathrm{C} / 30^{\circ} \mathrm{C}$. These houses therefore had no need for improved heating system control to provide the necessary space heating with low-temperature district heating. 


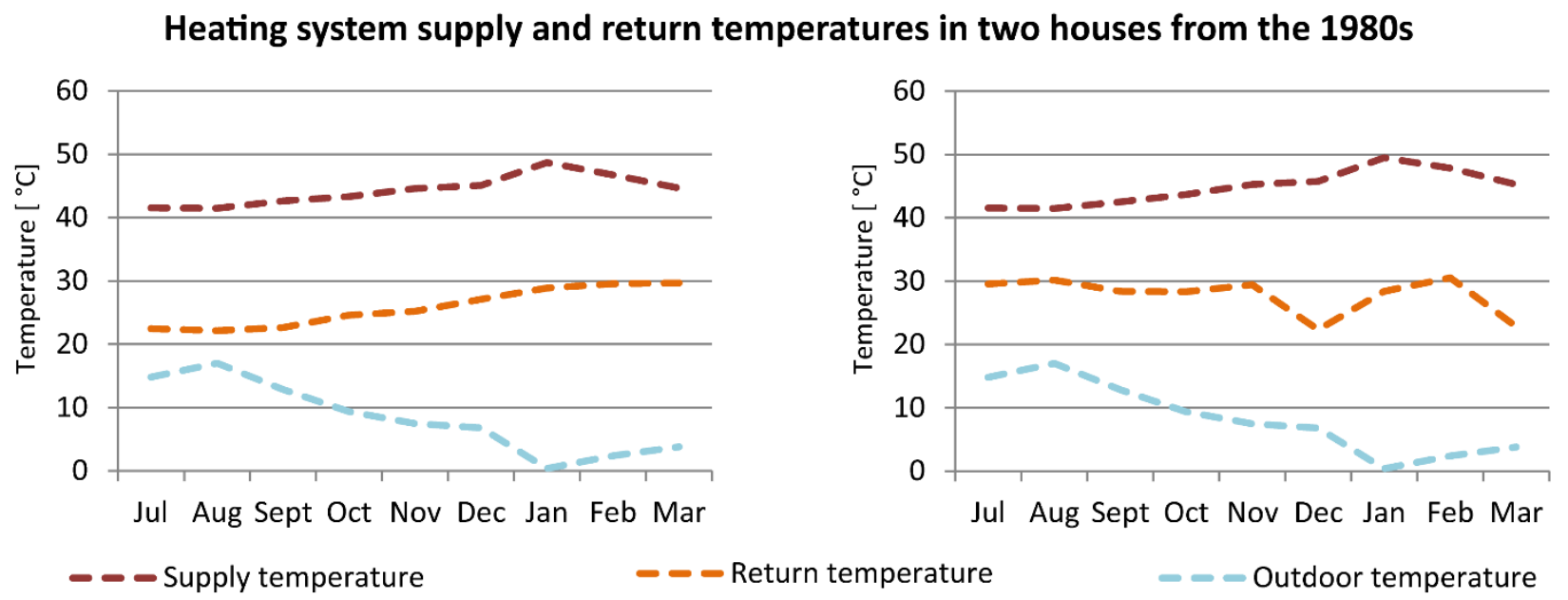

Fig. 2. Heating system temperatures measured in two single-family houses from the 1980s [25]

In the remaining three houses, we found that heating system design and control were a barrier to reducing heating system temperatures. The radiator return temperatures indicated that the high return temperatures of just a few radiators mainly caused the high overall heating system return temperature [27]. The result is illustrated in Fig. 3, which shows the average measurements of heating system return temperatures in two of the houses investigated. The colour codes indicate whether the average measured return temperatures were high (red) or low (blue) and show that three radiators in House 2 had high radiator return temperatures that seemed to contribute greatly to the high overall return temperature.

\section{Measured radiator return temperatures in two houses from the 1930s}

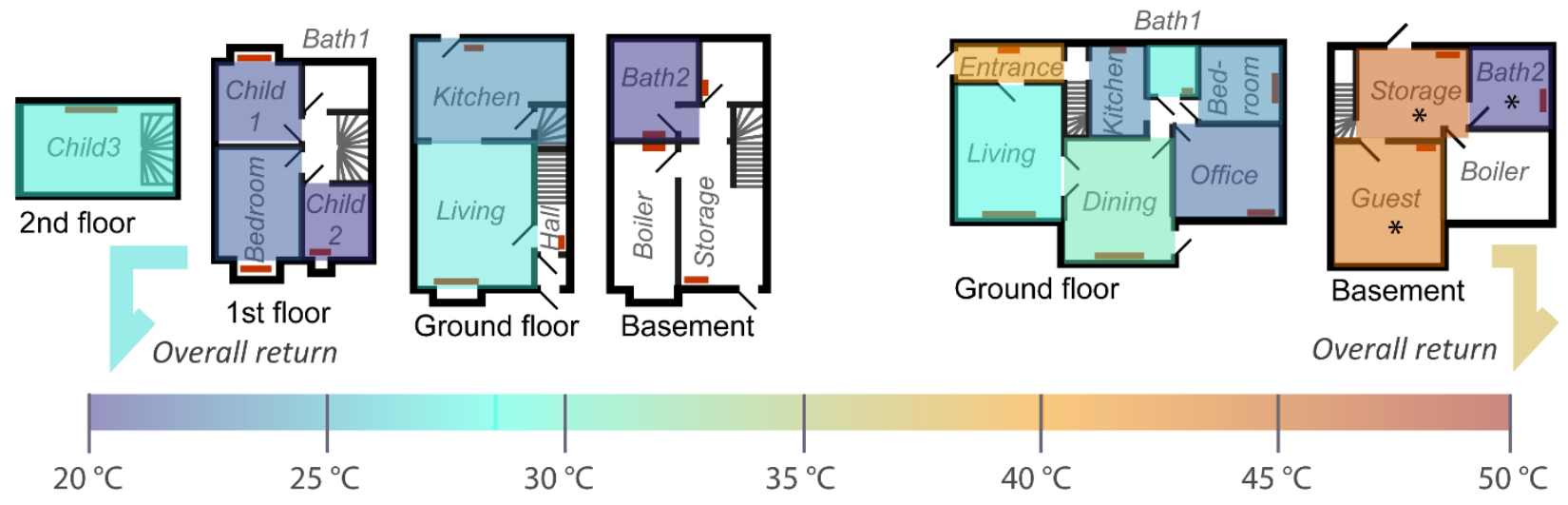

Fig. 3. Measured return temperatures in radiators and overall heating system in two houses from the 1930s [27] 
The results indicate that the main problem with current heating system control is poor hydraulic control in the heating systems, which leads to excess water flows and high return temperatures in some radiators. These problems may be owing to the relationship among pump operation, radiator valves, and thermostat control. Other studies have similarly shown how these control components can have a large influence on heating system temperatures, occupant thermal comfort, and energy consumption for heating [28-30]. Where issues with high return temperatures are identified, the main action required to ensure proper heating system control in existing buildings seems to be improving the hydraulic control of the heating system.

There are various tools available to improve heating system control. First, the correct pump should be installed, and thermostats should be installed to control the water mass flow through each heating element. For the thermostat to work properly, the correct valve must be installed. However, because it can be difficult to ensure efficient and robust correction of heating system faults using available components, we further suggested the development of two new tools to improve heating system control. The first suggestion was the development of a new electronic thermostat with an added return temperature sensor. The thermostat should be able to limit the water mass flow through the valve based on both the indoor temperature set-point and the maximum radiator return temperature. This would prevent unnecessary excess water mass flows through the radiator. The second suggestion was the development of a new pump control system that would ensure that the pressure in the heating system matches the actual heat load situation in the building. This would prevent high pressure from leading to extreme excess water flows through some heating system components. These two components were evaluated as potential alternative tools for improving heating system control in the future.

Based on this input, we defined four different hypothetical technical improvements that could help reduce the heating system return temperature in a home with high district heating return temperatures. The four solutions are given in Table 2. 
Table 2. Four hypothetical solutions to reduce heating system return temperatures in a building

\begin{tabular}{|l|l|}
\hline 1 & Pump, new radiator valves \\
\hline 2 & Pump, improved pump control \\
\hline 3 & Pump, improved pump control, return temperature thermostats \\
\hline 4 & Replacement of $40 \%$ of radiators \\
\hline
\end{tabular}

For the Danish energy system in total, two different scenarios were considered regarding the necessary heating system improvements to implement low-temperature district heating by 2050 . The first scenario was considered a worst-case scenario, in which the necessary improvements in heating system control were based on the current heating system controls identified in recent studies. This scenario thus does not consider the improvements in heating system control that will occur naturally during the next 30 years. In this scenario, we estimated that, apart from the $3 \%$ of radiators that need replacement, all buildings would benefit from an improved pump control system, and a further $40 \%$ of buildings would need improved heating system control to ensure low district heating return temperatures. These further heating system improvements were assumed to consist of the installation of a new pump and the installation of either new radiator valves or new thermostats that include return temperature sensors. This is a rather high estimate considering the results, in which improved heating system control was needed only for some of the heating elements in three of nine houses. However, we chose $40 \%$ to attempt a realistic worst-case estimate, which allows for situations that may occur in other types of buildings than those included in this study.

In the second scenario, we expected that some improvements in the heating systems will be carried out in connection with the general maintenance of the heating systems and the end-of-life of current heating system components before 2050. In this scenario, we therefore assumed that problematic radiators and old pumps were replaced to improve occupant comfort, ensure energy savings, and reduce the number of occupant complaints in rental buildings. New improved pump control was still expected to be needed in all buildings, and new radiator valves and new thermostats with return temperature sensors were assumed to be needed on $10 \%$ and $20 \%$ of existing radiators, respectively. The scenarios are summarised in Table 3 . 
Table 3. Implementation of solutions in the existing building stock in the two scenarios

\begin{tabular}{|l|l|l|}
\hline Action & $\begin{array}{l}\text { Scenario 1 } \\
\text { [\% of buildings] }\end{array}$ & $\begin{array}{l}\text { Scenario 2 } \\
\text { [\% of buildings] }\end{array}$ \\
\hline Improved pump control & $100 \%$ & $100 \%$ \\
\hline Return temperature thermostat & $20 \%$ & $20 \%$ \\
\hline New pump & $40 \%$ & - \\
\hline New radiator valve & $20 \%$ & $10 \%$ \\
\hline Radiator & $3 \%$ & - \\
\hline
\end{tabular}

\subsection{Costs of improving heating system control}

Table 4 shows the estimated costs of replacing problematic heating system components as calculated according to Equation 2. All prices include VAT.

Table 4. Costs of various improvements to heating system control (including VAT)

\begin{tabular}{|l|c|c|c|c|c|c|}
\hline \multirow{2}{*}{ Component } & \multicolumn{3}{|c|}{ Single-family house } & \multicolumn{3}{c|}{ Apartment building } \\
\cline { 2 - 8 } & $\begin{array}{l}\text { Work hours } \\
\text { [h/unit] }\end{array}$ & $\begin{array}{l}\text { Component cost } \\
\text { [EUR/unit] }\end{array}$ & $\begin{array}{l}\text { Total } \\
\text { [EUR/unit] }\end{array}$ & $\begin{array}{l}\text { Work hours } \\
\text { [h/unit] }\end{array}$ & $\begin{array}{l}\text { Component cost } \\
\text { [EUR/unit] }\end{array}$ & $\begin{array}{l}\text { Total } \\
\text { [EUR/unit] }\end{array}$ \\
\hline Pump & 2 & 200 & 340 & 4 & 530 & 810 \\
\hline Radiator valve & 0.5 & 30 & 65 & 0.25 & 30 & 47.5 \\
\hline Radiator & 1.5 & 400 & 505 & 1.2 & 400 & 484 \\
\hline Improved pump control & 3 & - & 210 & 8 & - & 560 \\
\hline Return temperature thermostat & 0.15 & 48 & 58.5 & 0.15 & 48 & 58.5 \\
\hline
\end{tabular}

The total costs incurred by individual homeowners were calculated according to Equation 3 for each of the four hypothetical heating system improvements listed in Table 2 . The results are given in Table 5 for both a standard single-family house and a standard apartment building.

Table 5. Four hypothetical solutions to reduce heating system return temperatures and the cost of these solutions

\begin{tabular}{|c|c|c|}
\hline$\sqrt{x+2 y}$ & $\begin{array}{c}\text { Single-family house } \\
\text { [EUR] }\end{array}$ & $\begin{array}{c}\text { Apartment building } \\
\text { [EUR] }\end{array}$ \\
\hline Pump, new radiator valves & 990 & 6985 \\
\hline Pump, improved pump control & 550 & 1370 \\
\hline Pump, improved pump control, return temperature thermostats & 1135 & 8975 \\
\hline Replacement of $40 \%$ of radiators & 2020 & 26538 \\
\hline
\end{tabular}


For the total Danish energy system, the costs of the necessary heating system improvements were calculated according to Equation 4. Table 6 shows the cost of each action in EUR/MWh for either singlefamily houses or apartment buildings.

Table 6. Costs of various improvements to heating system control per MWh of heat produced

\begin{tabular}{|l|c|c|}
\hline & $\begin{array}{c}\text { Single-family house } \\
\text { [EUR/MWh] }\end{array}$ & $\begin{array}{c}\text { Apartment building } \\
\text { [EUR/MWh] }\end{array}$ \\
\hline Pump & 19.0 & 3.7 \\
\hline Radiator valve & 36.4 & 28.4 \\
\hline Radiator & 282.9 & 288.9 \\
\hline Improved pump control & 11.8 & 2.6 \\
\hline Return temperature thermostat & 32.8 & 34.9 \\
\hline
\end{tabular}

The total cost of preparing Danish heating systems for low-temperature district heating by in 2050 were thus calculated to be 21.96-42.27 EUR/MWh for single-family houses and 12.39-25.96 EUR/MWh for apartment buildings considering the percentage of components needing replacement in the two scenarios given in Table 3.

\subsection{Simple payback time for the individual homeowner}

According to Equations 6 and 7, the savings and bonus achieved from the reduction in return temperatures in a single-family house would amount to EUR 108 per year or EUR 192 per year, depending on whether the house is in Copenhagen or in $\mathrm{H} \varnothing \mathrm{je}$ Taastrup, respectively. The savings and bonus achieved in the apartment building would amount to EUR 1713 per year or EUR 5388 per year, depending on whether the apartment building is in Copenhagen or $\mathrm{H} \varnothing \mathrm{je}$ Taastrup, respectively.

The simple payback time in years for each of the solutions was calculated according to Equation 8 and is illustrated in Fig. 4. 


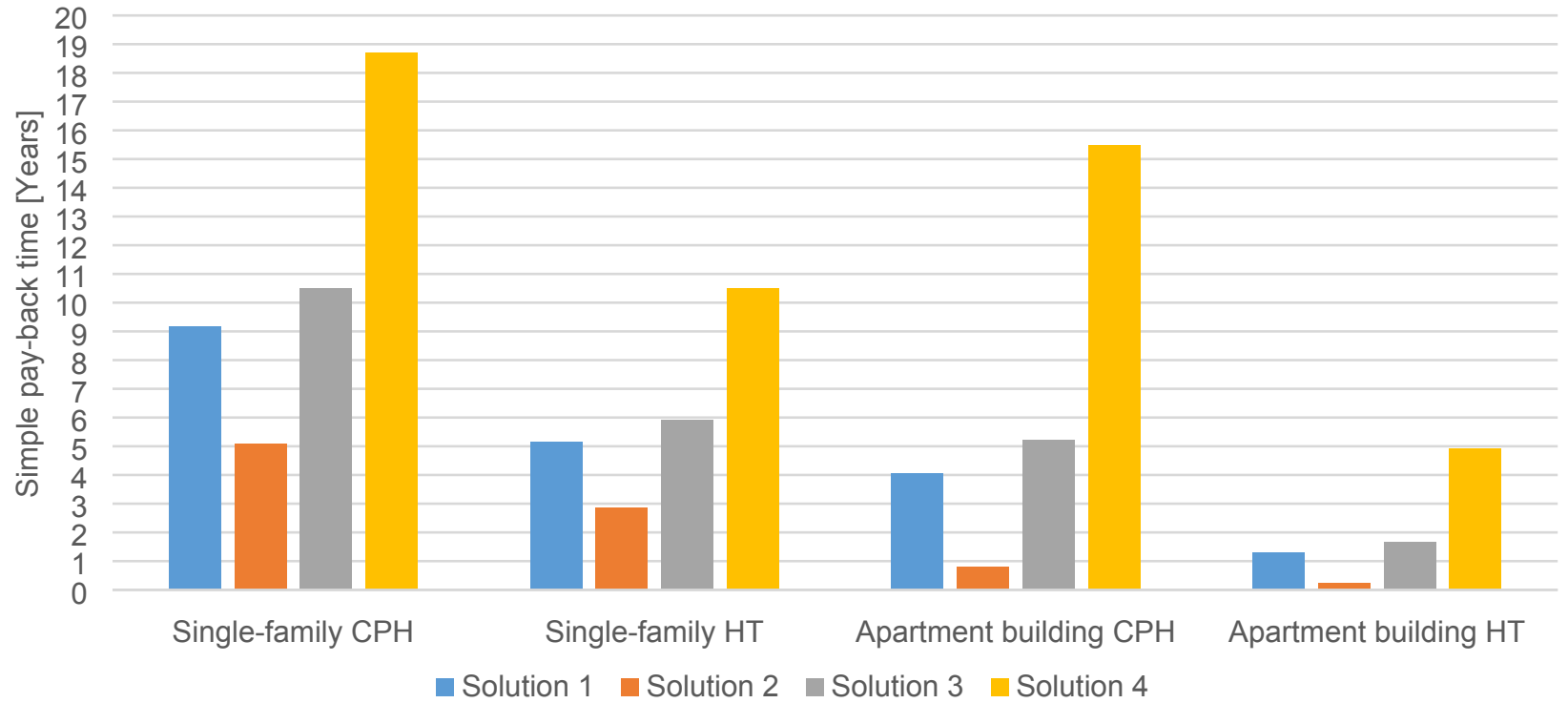

Fig. 4. Simple payback time for customers' investments in improved heating system control in Copenhagen (CPH) and Høje Taastrup (HT).

As the figure shows, the customers will often have a short payback time for their investments in improved heating system control. It is clear that the payback time is shorter in $\mathrm{H} \varnothing \mathrm{je}$ Taastrup than in Copenhagen, and payback times are shorter with higher original return temperatures. Thus, the scenario with the shortest payback time is the apartment building with a $53{ }^{\circ} \mathrm{C}$ return temperature in $\mathrm{H} \varnothing j \mathrm{je}$ Taastrup. Replacement of radiators is the solution with the longest payback time, and the payback time for this solution is in some cases so long, that this investment should be motivated by other factors such as improved thermal comfort in addition to the economic incentive. All other solutions have payback times less than approximately ten years. The results also highlight that if improved pump control can be carried out at the estimated low cost and have as significant an impact on heating system temperatures as indicated in ongoing research, this solution is very cost efficient, even where it must be combined with new valves or thermostats.

\subsection{Costs and benefits from an energy system perspective}

Fig. 5 illustrates the simple payback time of preparing Danish heating systems for low-temperature district heating, as calculated according to Equation 9. It should be noted that the costs cover only the space 
heating system and that additional investments are expected to be necessary in the domestic hot water system. The upper line represents the simple payback time for single-family houses, and the lower line is the simple payback time for apartment buildings.

\section{Simple payback time}

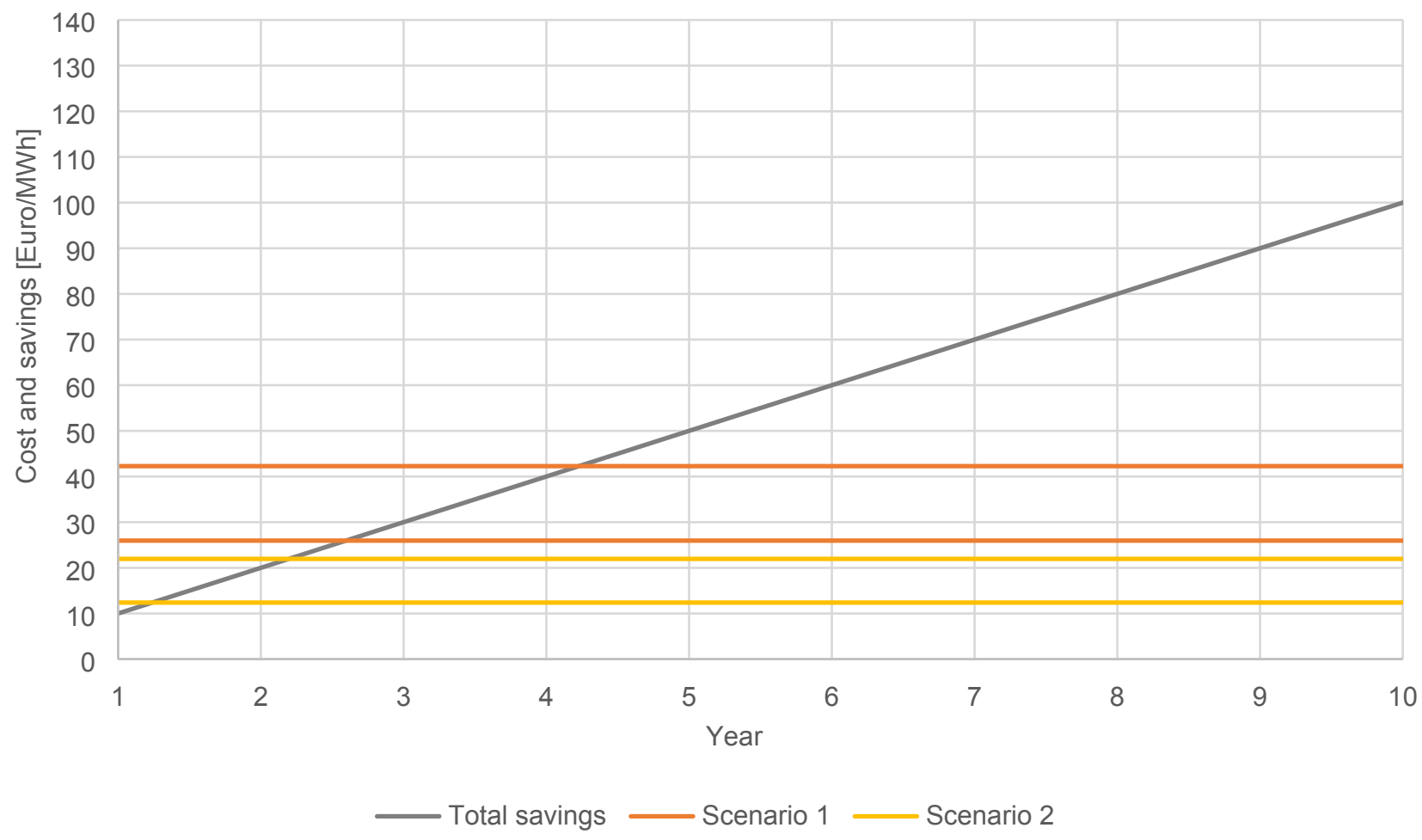

Fig. 5. Simple payback time for preparing existing space heating systems for low-temperature district heating.

As the figure shows, it is generally very feasible to implement $4^{\text {th }}$ generation district heating with its benefits compared to the cost of the improvements that will be necessary in current heating systems. The simple payback time on the investments in the heating systems is approximately four years in the worstcase scenario, whereas it is less than two years in the best-case scenario.

\section{Discussion}

The current results indicate the feasibility of preparing existing space heating systems for low-temperature district heating. However, the estimated costs include a great deal of uncertainty. The main uncertainty 
arises from the fact that the estimated costs are not based on actual demonstration projects, which means it has still not been verified whether the suggested actions can help reduce current return temperatures to the expected $30{ }^{\circ} \mathrm{C}$. Another uncertainty arises because prices for proposed future components are difficult to estimate. Finally, the studies were mainly concerned with Danish single-family houses. Owing to these uncertainties, it should be stressed that this study provides merely a first simple indication of the costs and benefits of preparing existing heating systems for low-temperature district heating. To underscore the findings of this paper, further research in the area, including insights from other building typologies and other countries, should be encouraged.

District heating return temperatures of $25-30^{\circ} \mathrm{C}$ are not very common today, but this does not mean that such low temperatures cannot be accomplished. A well-functioning radiator should be capable of ensuring a high delta $T$ over the radiator surface, thus ensuring that proper heating is delivered inside the dwelling when return temperatures are also kept low. This is supported by the measurements from the four singlefamily houses considered in this study, where heating system return temperatures were found to be below $30{ }^{\circ} \mathrm{C}$ for a large part of the year [23]. Similarly, a recent study by Jangsten et al. [31] also found that some heating systems already have heating system return temperatures below $30^{\circ} \mathrm{C}$ for a large part of the year, and a general analysis by Petersson and Werner [20] indicated that district heating return temperatures as low as $29^{\circ} \mathrm{C}$ should be obtainable if heating system control of current heating systems is optimised. Considering future expected building refurbishments and heat losses in the district heating return pipes, it therefore seems possible that district heating return temperatures as low as $25-30^{\circ} \mathrm{C}$ could be obtained in the future.

Despite the uncertainties and limitations of the study, it should be stressed that the present results are well in line with other results on similar topics. For example, several other studies have shown that components in existing heating systems are often over-dimensioned [7,32-35], which supports the findings in this study that only a few heating elements must be replaced to implement low-temperature space heating. 
Furthermore, other studies have additionally noted that improved hydraulic balancing in heating systems and improved heating system control can be obtained by installing the proper pumps, radiator valves, and thermostats and that such installations will cause a great benefit for the operation of existing heating systems $[28,29]$. In this regard, Trüschel [28] found that hydraulic balancing of the heating system in an apartment building can lead to lowered heating system temperatures, energy savings, or improved occupant comfort and therefore has resulting payback times between 1.5 years and 6.5 years, which is in line with the results of this study. The scenarios are also well in line with the costs for improved heating system control identified for northern Germany in [29]. In that study, the costs of improved heating system control were estimated to be in the range of EUR 2-7 per $\mathrm{m}^{2}$, whereas the costs in the current study range from EUR 0.7 to 13.5 per $\mathrm{m}^{2}$ but generally also cover a wider scale of improvements.

Even if the overall uncertainties and assumptions taken in this study mean that the cost of improved heating system control may be higher than estimated, the savings could also be significantly higher than estimated. Additional savings that were not considered in this study include both energy savings and fewer occupant complaints, which may add up to savings on the order of $15 \%$ of the energy consumption or EUR 1300 per year owing to less time being spent on complaints, as Trüschel noted [28]. Furthermore, a new pump installation will typically lead to considerable savings in electricity, which can be on the order of EUR 50 in a Danish single-family house with electricity costs of approximately EUR 0.26 per $\mathrm{kWh}$ if a $40-\mathrm{W}$ pump is replaced by a new 5-W pump. Additionally, the increased comfort of occupants is a benefit that was not included in this study and can be difficult to quantify. In all, we therefore believe that the current analysis provides a reasonable estimate of the feasibility of preparing existing buildings for low-temperature district heating, within the limits of the information available on the topic.

\section{Conclusion}

This study estimated the costs and benefits of preparing heating systems in existing buildings for lowtemperature district heating. The results indicate that it is feasible to invest in improved heating system 
control to make it possible to reduce district heating temperatures. The estimated investments needed were found to have simple payback times of between 0.3 years and 18.7 years for the individual customer and between 1.3 years and 4.2 years when the total energy system is considered. The savings for the district heating customer were based on the use of return temperature tariff schemes currently used in Denmark, so the results highlight the importance of implementing such schemes to provide an economic incentive for customers to invest in improved heating system control. Only in this way will it be possible to realise the transition to low-temperature district heating and thus reduce the general cost of producing energy. Thus, this study shows that there is good reason to continue work on ways to prepare existing buildings for low-temperature district heating. This work could include the development of new efficient tools for improved heating system control and for facilitating the correction of current heating system malfunctions to ensure the continuous robust operation of heating systems.

\section{Acknowledgements}

The work presented in this article was a result of the research activities of the Strategic Research Centre for 4th Generation District Heating (4DH), which received funding from the Innovation Fund Denmark. 


\section{References}

[1] Lund H, Werner S, Wiltshire R, Svendsen S, Thorsen JE, Hvelplund F, et al. 4th Generation District Heating (4GDH): Integrating smart thermal grids into future sustainable energy systems. Energy 2014;68:1-11. doi:10.1016/j.energy.2014.02.089.

[2] Connolly D, Lund H, Mathiesen B V., Werner S, Möller B, Persson U, et al. Heat roadmap Europe: Combining district heating with heat savings to decarbonise the EU energy system. Energy Policy 2014;65:475-89. doi:10.1016/j.enpol.2013.10.035.

[3] Danish Energy Agency. Energy statistics 2013. 2014.

[4] Dalla Rosa A, Christensen JE. Low-energy district heating in energy-efficient building areas. Energy 2011;36:6890-9. doi:10.1016/j.energy.2011.10.001.

[5] Dansk Fjernvarmes F\&U konto. Etablering af lavtemperaturfjernvarme i eksisterende fjernvarmeforsyning [Establishment of low-temperature district heating in existing district heating systems]. COWI: 2014.

[6] International Energy Agency. IEA DHC | CHP Annex TS1 Low Temperature District Heating for Future Energy Systems Subtask D : Case studies and demonstrations. 2016.

[7] Danish Energy Agency, EUDP 2010-II. Demonstration i Tilst Energistyrelsen - Fuldskala demonstration af lavtemperatur fjernvarme i eksisterende bebyggelser - Journalnr. 64010-0479 [Demonstration in Tilst - Full scale demonstration of low-temperature district heating in existing buildings]. 2014.

[8] Danish Energy Agency, EUDP 2010-II. Demonstration i Sønderby - Fuldskalademonstration af lavtemperaturfjernvarme i eksisterende bebyggelser - Journalnr. 64010-0479 [Demonstration in Sønderby - Full scale demonstration of low-temperature district heating in existing buildings]. 2014.

[9] Brand $M$, Svendsen S. Renewable-based low-temperature district heating for existing buildings in various stages of refurbishment. Energy 2013;62:311-9. doi:10.1016/j.energy.2013.09.027.

[10] Frederiksen S, Werner S. District heating and cooling. Studentlitteratur; 2013.

[11] Zinko H, Lee H, Kim B-K, Kim Y-H, Lindkvist H, Loewen A, et al. Improvement of operational temperature differences in district heating systems. 2005.

[12] Averfalk H. Morgondagens effektiva fjärrvärme En beskrivande litteraturstudie. 2014.

[13] Lund H, $\varnothing$ steraard PA, Chang M, Werner S, Svendsen S, Sorknæs P, et al. The status of 4th generation district heating: research and results. Energy n.d.

[14] Lauenburg P. Temperature optimization in district heating systems. Elsevier Ltd.; 2016. doi:10.1016/B978-1-78242-374-4.00011-2.

[15] Ommen T, Markussen WB, Elmegaard B. Lowering district heating temperatures - Impact to system performance in current and future Danish energy scenarios. Energy 2016;94:273-91. doi:10.1016/j.energy.2015.10.063.

[16] Danish Energy Agency, EUDP 2008-II. CO2-reductions in low energy buildings and communities by implementation of low-temperature district heating systems. Demonstration cases in EnergyFlexHouse and Boligforeningen Ringgården - Journalnr. 63011-0152. DTU BYG: 2011.

[17] Lund R, Østergaard DS, Yang X, Mathiesen BV. Comparison of Low-temperature District Heating Concepts in a Long-Term Energy System Perspective (In review). Int J Sustain Energy Plan Manag 
2017;12:5-18. doi:10.5278/ijsepm.2017.17.x.

[18] Averfalk H, Werner S, Felsmann C, Rühling K, Wiltshire R, Svendsen S, et al. Annex XI final report: Transformation Roadmap from High to Low Temperature District Heating Systems. 2017.

[19] Østergaard DS, Svendsen S. Theoretical overview of heating power and necessary heating supplytemperatures in typical Danish single-family houses from the 1900s. Energy Build 2016;126:375-83.

[20] Petersson S, Werner S. Långtidsegenskaper hos lågflödesinjusterade radiatorsystem. 2003.

[21] Østergaard DS, Svendsen S. Are typical radiators over-dimensioned? An analysis of radiator dimensions in 1645 Danish houses. Energy Build n.d.

[22] Østergaard DS, Svendsen S. Replacing critical radiators to increase the potential to use lowtemperature district heating - A case study of 4 Danish single-family houses from the 1930s. Energy 2016;110:75-84. doi:10.1016/j.energy.2016.03.140.

[23] Østergaard D, Svendsen S. Space heating with ultra-low-temperature district heating - A case study of four single-family houses from the 1980s. Energy Procedia 2017;116:226-35. doi:10.1016/j.egypro.2017.05.070.

[24] Danish Standards. DS 418:2011 - Beregning af bygningers varmetab [Calculation of heat loss from buildings]. 2011.

[25] Østergaard D, Svendsen S. Space heating with ultra-low-temperature district heating - A case study of four single-family houses from the 1980s. Energy Procedia, vol. 116, 2017. doi:10.1016/j.egypro.2017.05.070.

[26] Molio - Byggeriets Videncenter. Molio prisdata [Molio price data] n.d. https://molio.dk/molioprisdata/\# (accessed August 2, 2018).

[27] Østergaard DS, Svendsen S. Experience from a practical test of low-temperature district heating for space heating in five Danish single-family houses from the 1930s. Energy 2018;159:569-78. doi:10.1016/j.energy.2018.06.142.

[28] Trüschel A. Värdet av injustering [The value of balancing]. Svensk Fjärrvärme [Swedish District Heating]; 2005.

[29] Ahern C, Norton B. Energy savings across EU domestic building stock by optimizing hydraulic distribution in domestic space heating systems. Energy Build 2015;91:199-209. doi:10.1016/j.enbuild.2015.01.014.

[30] Cholewa T, Siuta-Olcha A, Balaras CA. Actual energy savings from the use of thermostatic radiator valves in residential buildings - Long term field evaluation. Energy Build 2017;151:487-93. doi:10.1016/j.enbuild.2017.06.070.

[31] Jangsten M, Kensby J, Dalenbäck JO, Trüschel A. Survey of radiator temperatures in buildings supplied by district heating. Energy 2017;137:292-301. doi:10.1016/j.energy.2017.07.017.

[32] Andersen NB, Grimmig M. Lavtemperaturvarme i Eksisterende Boliger [Low-temperature heating in existing homes]. The Danish Technological Institute; 1988.

[33] Jørgensen B. Lavtemperaturdrift af eksisterende fjernvarmenet [Low-temperature operation of existing district heating networks]. The Danish Technological Institute; 1988.

[34] Peeters L, Van der Veken J, Hens H, Helsen L, D'haeseleer W. Control of heating systems in residential buildings: Current practice. Energy Build 2008;40:1446-55. 
doi:10.1016/j.enbuild.2008.02.016.

[35] Hasan A, Kurnitski J, Jokiranta K. A combined low temperature water heating system consisting of radiators and floor heating. Energy Build 2009;41:470-9. doi:10.1016/j.enbuild.2008.11.016. 


\section{Highlights:}

- Low-temperature heating can be implemented at low costs from a long-term perspective

- Investments in heating systems are attractive from an energy system perspective

- Customer investments in heating systems should be motivated economically 